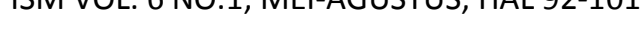

\title{
Hubungan Status Depresi terhadap Kualitas Hidup Lansia di Wilayah Kerja Puskesmas Petang II Kabupaten Badung Bali Tahun 2015
}

\author{
Sri Chandra Kumar Kathiravellu \\ Program Studi Pendidikan Dokter, Fakultas Kedokteran Universitas Udayana \\ (kumar.blackhawk@gmail.com)
}

\begin{abstract}
ABSTRAK
Pendahuluan: Fenomena population aging di wilayah kerja Puskesmas Petang II dapat menimbulkan masalah baru terkait kualitas hidup lansia. Berdasarkan penelitian yang telah dilakukan, diketahui beberapa faktor terkait seperti status depresi memiliki peran yang besar dalam mempengaruhi kualitas hidup lansia. Tujuan dari penelitian ini adalah untuk mengetahui hubungan antara status depresi terhadap kualitas hidup lansia di wilayah kerja Puskesmas Petang II sehingga dapat dijadikan acuan dalam pengembangan program kesehatan lansia.
\end{abstract}

Metodologi: Penelitian ini merupakan penelitian deskriptif cross-sectional analitik yang melibatkan 93 lansia yang tinggal di wilayah kerja Puskesmas Petang II sebagai responden. Data mengenai karakteristik sosiodemografi, dan penyakit kronis pada lansia diperoleh melalui wawancara terstruktur dengan kuesioner, data status depresi dan kualitas hidup didapatkan melalui wawancara dengan kuesioner yang spesifik yakni kuesioner GDS dan WHOQOL BREF. Data selanjutnya dianalisis secara univariat dan bivariat terstratifikasi dengan program komputer.

Hasil: Kualitas hidup lansia di wilayah kerja Puskesmas Petang II secara umum telihat lebih banyak jumlah lansia memiliki kualitas hidup buruk (50,5\%) namun dengan selisih yang kecil dibandingkan kualitas hidup baik. Hasil uji chi-square antara status depresi menunjukkan hubungan yang signifikan dengan kualitas hidup lansia.

Simpulan: Hubungan yang bermakna ditunjukkan antara status depresi terhadap kualitas hidup lansia. Lansia yang tidak mengalami depresi memiliki kecendrungan tinggi untuk memiliki kualitas hidup yang baik.

Kata Kunci: lansia, kualitas hidup, status depresi

\section{PENDAHULUAN}

Dewasa ini telah terjadi revolusi demografis global yang ditandai adanya pergeseran gambaran piramida penduduk dimana proporsi penduduk dengan usia lebih dari 60 tahun (lansia) mengalami peningkatan yang lebih cepat dibandingkan kelompok usia lainnya. Hal yang menarik perhatian adalah percepatan pertumbuhan populasi lansia lebih tinggi di negara berkembang dengan jumlah penduduk lansia yang meningkat lima kali lipat dalam kurun waktu 8 tahun dan diprediksi akan terus meningkat menjadi 1,6 milyar pada tahun 2050. ${ }^{1}$ Di Indonesia, data Survei Sosial dan Ekonomi Nasional (Susenas) tahun 2012 menunjukkan persentase jumlah lansia adalah sebesar 7,56\% atau setara dengan 18,96 juta. Data jumlah lansia di Provinsi Bali menunjukkan suatu tren peningkatan dari 7,2\% tahun 2006 menjadi 9,4\% pada tahun 2011. ${ }^{2}$ Fenomena revolusi demografis serupa juga telihat di wilayah kerja Puskesmas Petang II dimana terjadi proporsi lansia pada tahun 2013 mencapai 11,68\% dari total penduduk (Laporan Tahunan Program Lansia Puskesmas Petang II, 2012).

Serangkaian proses penuaan pada lansia menyebabkan lansia mengalami kemunduran fisik, psikologis, maupun kehidupan sosialnya yang berdampak pada kualitas hidup lansia. ${ }^{3-5}$ Pada lansia, penurunan kesehatan fisik memiliki pengaruh yang lebih besar terhadap penurunan kualitas hidup dibandingkan kelompok usia lainnya. ${ }^{6}$ Penurunan fungsi kognitif akibat proses 
penuaan juga dikaitkan dengan penurunan kualitas hidup. Penelitian Sethi (2012) mengungkapkan bahwa gangguan kognitif rentan terjadi pada lansia seiring dengan penurunan aktivitas dan interaksi sosial dari lansia tersebut. Proses adaptasi yang harus dijalani terhadap segala perubahan yang dialami membuat lansia rentan mengalami gangguan psikologis seperti kondisi emosi yang tidak stabil, depresi, atau ansietas sehingga dapat menurunkan kualitas hidup lansia. Selain itu, perubahan tempat tinggal seperti tinggal dengan keluarga yang lain atau tinggal sendiri di rumah dapat mempengaruhi kualitas hidup lansia. ${ }^{5}$

Lansia merupakan kelompok yang rentan terhadap ancaman penyakit degeneratif yang umumnya bersifat kronis. ${ }^{7,8}$ Berdasarkan data Riset Kesehatan Dasar (Riskesda) tahun 2013, prevalensi tertinggi penyakit kronis seperti kanker, diabetes mellitus, hipertensi, penyakit jantung koroner dan gagal jantung ditemukan pada kelompok usia $\geq 65$ tahun. Sebagai akibat dari penyakit kronis, perjalanan penyakit dan komorbiditas serta beban kesehatan dan ekonomi yang ditimbulkan dapat mempengaruhi kehidupan lansia, termasuk keluarga dan komunitas secara keseluruhan. ${ }^{7}$ Salah satu dampak terbesar yang dapat timbul adalah depresi pada lansia.

Kualitas hidup merupakan isu strategis yang mencerminkan kondisi lansia dalam menikmati sisa usianya dan bersiap untuk meninggal dengan damai. Oleh karena itu, faktor-faktor yang dapat mempengaruhi kualitas hidup lansia hendaknya dapat diakomodasi baik oleh lansia, keluarga maupun health provider. Salah satu penyedia layanan kesehatan pada lini pertama adalah

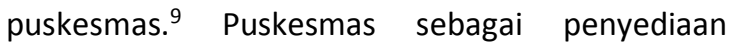
layanan kesehatan yang sekaligus berperan sebagai pusat pengembangan kesehatan masyarakat (center for community health development) di wilayah kerjanya hendaknya mengembangkan program kesehatan berdasarkan permasalahan yang berkembang di masyarakat, termasuk permasalahan pada penduduk lansia. ${ }^{9}$ Tingginya jumlah lansia di wilayah kerja Puskesmas Petang II hendaknya diantisipasi dengan upaya upaya untuk meningkatkan dan mempertahankan kualitas hidup yang optimal pada lansia. Guna meningkatkan derajat kesehatan lansia di wilayahnya, Puskesmas Petang II telah memiliki upaya kesehatan lansia dengan program pokoknya berupa Pos Pelayanan Terpadu (Posyandu) Lansia. Namun untuk saat ini Posyandu yang berjalan masih hanya mencakupi 5 Banjar dari 18 Banjar yang terdapat di wilayah kerja Puskesmas Petang II. Pencatatan lansia juga belum dilakukan dengan lengkap di masing-masing banjar di wilayah kerja Puskesmas Petang II. Disamping itu, kegiatan posyandu lansia yang dilakukan selama ini hanya terbatas pada upaya peningkatan kesehatan fisik seperti pemeriksaan kesehatan dan pengobatan gratis, pengukuran berat badan dan tinggi badan, pemberian makanan gratis dan senam lansia.

Adanya data mengenai kualitas hidup lansia serta faktor yang memiliki hubungan terkuat dengan kualitas tersebut tentunya dapat dijadikan acuan dalam mengembangkan program kesehatan lansia yang lebih komprehensif. Akan tetapi, data tersebut belum tersedia dan belum pernah dilakukan evaluasi terhadap kualitas hidup lansia di wilayah kerja Puskesmas Petang II.

Bertolak dari fakta dan hal yang dipaparkan di atas maka penelitian ini dilakukan untuk mengetahui hubungan antara tingkat depresi dengan kualitas hidup lansia di wilayah kerja Puskesmas Petang II. Penelitian ini diharapkan dapat memberikan informasi dalam perencanaan dan keberlanjutan program puskesmas yang tepat dan sesuai dengan kebutuhan lansia guna meningkatkan kualitas hidup lansia di wilayah kerja Puskesmas Petang II.

\section{METODE PENELITIAN}

\section{Rancangan Penelitian}

Penelitian ini menggunakan desain penelitian observasional analitik dengan pendekatan cross sectional berupa survei lapangan. Survei lapangan dilakukan untuk mempelajari hubungan tingkat depresi dengan kualitas hidup lansia di wilayah kerja Puskesmas Petang II.

\section{Tempat dan Waktu Penelitian}

\section{Tempat Penelitian}

Penelitian ini dilaksanakan di wilayah kerja Puskesmas Petang II yang meliputi 2 Desa yakni Desa Belok dan Pelaga.

\section{Waktu Penelitian}

Penelitian ini dilaksanakan pada bulan Maret 2015. 


\section{Populasi dan Sampel}

Populasi

Populasi penelitian adalah seluruh penduduk lansia yakni mereka yang berusia $\geq 60$ tahun dan berdomisili di wilayah kerja Puskemas Petang II.

\section{Besar Sampel}

Besar sampel dihitung menggunakan rumus sebagai berikut:

$$
n 1=n 2=\frac{(Z \alpha \sqrt{2 P Q}+Z \beta \sqrt{P 1 Q 1+P 2 Q 2})^{2}}{(P 1-P 2)^{2}}
$$

Dimana $P=1 / 2(P 1+P 2)$

Jumlah yang diperlukan

$\mathrm{Z} \alpha:$ : 1,96 pada confidence level $95 \%$

Zb $: 0,82$

P1 : $60 \%$ (proporsi lansia dengan kualitas hidup buruk dan fungsi keluarga tidak sehat. ${ }^{10}$

P2 : 9,7\% (proporsi lansia dengan kualitas hidup buruk dan fungsi keluarga sehat)

Q : $(1-\mathrm{P})$

Dari hasil tersebut diperoleh sampel minimal pada penelitian ini adalah 17 orang. Dalam penelitian ini jumlah sampel yang digunakan sebanyak 93 orang.

Dari hasil tersebut diperoleh sampel minimal pada penelitian ini adalah 17 orang. Dalam penelitian ini jumlah sampel yang digunakan sebanyak 93 orang.

\section{Cara Pengambilan Sampel}

Sampel dipilih dengan cara non random sampling yakni accidental sampling. Accidental sampling dilakukan dengan mengunjungi rumah lansia di wilayah kerja Puskesmas Petang II.

\section{Kriteria Inklusi}

Kriteria inklusi dalam penelitian ini adalah responden bertempat tinggal di wilayah kerja Puskesmas Petang II.

\section{Kriteria Drop Out}

Kriteria drop out dalam penelitian ini adalah :

1. Subyek menolak berpartisipasi dalam penelitian

2. Subyek menderita gangguan jiwa.

3. Subyek tidak kooperatif

4. Subyek mengalami tuna wicara

5. Subyek menderita demensia

6. Subyek menderita gangguan pendengaran hebat

\section{Responden Penelitian}

Sampel yang terpilih selanjutnya ditetapkan sebagai responden untuk memperoleh informasi tentang tingkat depresi, umur, jenis kelamin, tingkat pendidikan, satus pernikahan, pekerjaan, penyakit kronis yang diderita dan kualitas hidup pada kelompok lansia yang tinggal di wilayah kerja Puskesmas Petang II.

Variabel Penelitian

Adapun variabel yang diteliti adalah :

1. Variabel bebas: Tingkat depresi

2. Variabel terikat: Kualitas hidup lansia

3. Variabel perancu: Jenis kelamin, usia, tingkat pendidikan, status pernikahan, pekerjaan, penyakit kronis

\section{Instrumen Penelitian}

Instrumen yang digunakan dalam penelitian ini antara lain sebagai berikut:

1. Kuisioner untuk mencatat data demografi, sosial ekonomi, dan penyakit kronis.

\section{Kuisioner Geriatric Depresion Scale}

Intsrumen terdisi dari 15 pertanyaan yang bertujuan unutk menilai kejadian depresi pada lansia. Masing-masing pertanyaan dapat dijawab dengan "ya" atau "tidak", yang akan memberikan satu poin untuk salah satu jawaban tersebut. Pertanyaan nomor 1, 5, 7, 11, dan 13 apabila dijawab "ya" mendapat nilai 0, sedangkan apabila dijawab "tidak" mendapat nilai 1 . Sistem penilaian ini berlaku sebaliknya untuk 10 pertanyaan lainnya. Selanjutnya semua nilai dijumlahkan dan diinterpretasikan: 0-4 menunjukkan tidak depresi dan skor $\geq 5$ mengindikasikan depresi. Kuesioner ini juga telah tersedia dalam Bahasa Indonesia, sehingga peneliti tidak lagi menerjemahkan sendiri kuesioner ini ataupun melakukan uji validitas dan reliabilitas.

3. Kuisioner WHOQOL BREF untuk mendapatkan data kualitas hidup.

Kuesioner ini terdiri dari 26 pertanyaan dengan dua pertanyaan yang umum tentang kualitas hidup dan kepuasan hidup yang tidak dimasukkan kedalam skoring kualitas hidup dan 24 pertanyaan lainnya yang menyakut tentang keempat domain kualitas hidup. Penilaian kualitas hidup dengan menggunakan skala Likert dengan 
lima titik yang berkisar antara 1-5. Aspek dan distribusi item kuesioner kualitas hidup dapat dilihat pada lampiran.

Setiap item pertanyaan diberikan nilai 1, 2, 3, 4 dan 5 dengan dideskripsikan sebagai berikut:

a) Pada item pertanyaan nomor 3 dan 4 merupakan pertanyaan unfavorable dengan skor 1= dalam jumlah berlebihan, 2 = sangat sering, 3 = dalam jumlah sedang, $4=$ sedikit dan $5=$ tidak sama sekali, sedangkan untuk item pertanyaan 59 merupakan pertanyaan favorable $1=$ tidak sama sekali, 2 = sedikit, 3 = dalam jumlah sedang, $4=$ sangat sering dan $5=$ dalam jumlah berlebihan.

b) Pada item pertanyaan 10-14 merupakan pertanyaan favorable dengan skor $1=$ tidak sama sekali, 2 = sedikit, $3=$ sedang, $4=$ seringkali dan $5=$ sepenuhnya dialami.

c) Pada item pertanyaan nomor 15 merupakan pertanyaan favorable dengan skor $1=$ sangat buruk, 2 = buruk, 3 = biasa-biasa saja, 4 = baik dan 5 = sangat baik.

d) Pada item pertanyaan nomor 16-25 merupakan pertanyaan favorable dengan skor $1=$ sangat tidak memuaskan, 2= tidak memuaskan, 3= biasa-biasa saja, $4=$ memuaskan, $5=$ sangat memuaskan.

e) Pada item pertanyaan nomor 26 merupakan pertanyaan unfavorable dengan skor $1=$ selalu, $2=$ sangat sering, $3=$ kadang-kadang, $4=$ jarang dan $5=$ tidak pernah

Data gambaran kualitas hidup dideskripsikan berdasarkan akumulasi skor dari pengisian kuesioner WHOQOL BREF. Untuk dapat mencapai akumulasi skor tersebut, skor yang diperoleh harus melewati beberapa tahap, yaitu penentuan skor akhir untuk masing-masing domain dan transformasi skor. Tata cara penentuan skor akhir telah disajikan pada lampiran 1 dan transformasi skor pada lampiran 2.

Skor dari masing-masing domain kualitas hidup yang telah ditransformasi, kemudian diakumulasi lalu dibagi 4, kemudian diklasifikasi sebagai berikut: (1) Skor < 33 termasuk dalam kategori kualitas hidup rendah, (2) Skor $\geq 33$ dan < 67 termasuk dalam kategori dukungan kualitas hidup sedang, (3) Skor $\geq 67$ termasuk dalam kategori kualitas hidup tinggi.

Kuesioner WHOQOL BREF merupakan kuesioner yang dapat digunakan untuk mengukur kualitas hidup lansia. Kuesioner WHOQOL BREF ini dikeluarkan oleh WHO dan telah baku. Kuesioner ini tersaji dalam berbagai bahasa salah satunya Bahasa Indonesia. Jadi, peneliti tidak menterjemahkan sendiri kuesioner WHOQOL BREF ini melainkan sudah ada dalam bentuk Bahasa Indonesia. Untuk itu, peneliti tidak lagi melakukan uji validitas dan reabilitas terhadap kuesioner ini.

\section{Cara Pengumpulan data}

Pengumpulan data dilakukan dengan cara peneliti mewawancarai responden untuk kemudian mengisi kuesioner berdasarkan jawaban-jawaban dari responden. Kuesioner diberikan pada responden yang setuju diwawancarai setelah diberi inform consent. Dalam satu wawancara diperkirakan menghabiskan waktu 15-30 menit. Wawancara dilakukan sesuai dengan daftar pertanyaan atau kuesioner yang berisi pertanyaanpertanyaan sesuai dengan variabel-variabel yang diteliliti kepada responden.

\section{Analisis Data}

Setelah data terkumpul, data diolah dengan bantuan perangkat lunak dan data yang diperoleh akan dianalisis secara deskriptif (persentase).

\section{Analisis Univariat}

Merupakan analisis yang dilakukan terhadap tiap variabel dalam hasil penelitian. Pada analisis ini hanya menghasilkan distribusi persentase dan rata-rata untuk skor kualitas hidup masing-masing domain dan skor total kualitas hidup. Hasil analisis univariat disajikan dalam bentuk tabel dan narasi.

\section{Analisis Bivariat}

Analisis ini dilakukan dengan menggunakan tabulasi silang dengan uji chi-square, yaitu antara variabel fungsi keluarga, status kognitif dan status depresi terhadap kualitas hidup lansia. Uji statistik tersebut dilakukan untuk mengetahui hubungan antara variabel bebas dan variabel terikat pada penitian ini. Selanjutnya dilakukan analisis terstratifikasi berdasarkan variabel perancu seperti jenis kelamin, kelompok usia, status perkawinan, 


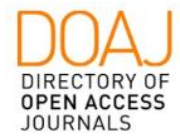

perkerjaan dan penyakit kronis, yang memiliki hubungan signifikan dengan kualitas hidup berdasarkan uji chi-square sehingga dapat diketahui ada tidaknya modifikasi dari variabel perancu tersebut terhadap hubungan antara variabel bebas dan terikat.

Definisi Operasional Variabel

\begin{tabular}{|c|c|c|c|c|c|c|}
\hline No & Variabel & Definisi Operasional & Cara Ukur & Alat Ukur & Hasil Ukur & Skala Ukur \\
\hline \multicolumn{7}{|c|}{ Status Depresi } \\
\hline 1. & $\begin{array}{l}\text { Status } \\
\text { Depresi }\end{array}$ & $\begin{array}{l}\text { Suatu gangguan mental } \\
\text { umum yang ditandai } \\
\text { dengan mood tertekan, } \\
\text { kehilangan kesenangan } \\
\text { atau minat, yang dinilai } \\
\text { dari skor dari pengisian } \\
\text { kuisioner GDS yang } \\
\text { terdiri dari } 15 \\
\text { pertanyaan }\end{array}$ & Wawancara & $\begin{array}{l}\text { Kuisioner } \\
\text { GDS-15 }\end{array}$ & $\begin{array}{l}\text { Dikategorikan dalam depresi } \\
\text { atau non depresi. }\end{array}$ & Ordinal \\
\hline
\end{tabular}

Karakteristik Demografi

\begin{tabular}{|c|c|c|c|c|c|c|}
\hline 1. & Usia & $\begin{array}{l}\text { Lama hidup lansia yang } \\
\text { dihitung dari tanggal } \\
\text { lahir hingga tanggal } \\
\text { pengambilan data }\end{array}$ & $\begin{array}{l}\text { Wawancaraa } \\
\text { tau } \\
\text { Pengecekan } \\
\text { KTP }\end{array}$ & Kuisioner & $\begin{array}{l}\text { Dikategorikan ke dalam } \\
\text { kelompok usia } 60-74 \text { dan } \\
\text { diatas } 75 \text { tahun }\end{array}$ & \\
\hline 2. & $\begin{array}{l}\text { Status } \\
\text { pendidikan }\end{array}$ & $\begin{array}{l}\text { Status pendidikan } \\
\text { adalah jenjang pen- } \\
\text { didikan formal ter-akhir } \\
\text { yang ditempuh oleh } \\
\text { lansia }\end{array}$ & Wawancara & Kuesioner & $\begin{array}{l}\text { Tingkat pendidikan } \\
\text { dikategorikan dalam tidak } \\
\text { bersekolah, tidak tamat SD, } \\
\text { tamat SD, SMP, SMA/SMK, } \\
\text { Perguruan Tinggi; dan } \\
\text { lainnya }\end{array}$ & Ordinal \\
\hline 3. & $\begin{array}{l}\text { Status } \\
\text { pernikahan }\end{array}$ & $\begin{array}{l}\text { Status pernikahan } \\
\text { lansia saat ini }\end{array}$ & Wawancara & Kuesioner & $\begin{array}{l}\text { Dikategorikan ke dalam } \\
\text { belum menikah, menikah, } \\
\text { duda/janda }\end{array}$ & Nominal \\
\hline 4. & Pekerjaan & $\begin{array}{l}\text { Pekerjaan lansia saat } \\
\text { ini. Pekerjaan disini } \\
\text { adalah pekerjaan yang } \\
\text { mendatangkan } \\
\text { pemasukan bagia } \\
\text { lansia. Dilihat dari ada / } \\
\text { tidaknya pekerjaan } \\
\text { yang mengahsilkan } \\
\text { uang yang dilakukan } \\
\text { lansia. }\end{array}$ & & & $\begin{array}{l}\text { Dikategorikan menjadi } \\
\text { bekerja dan tidak bekerja. }\end{array}$ & Nominal \\
\hline
\end{tabular}




\begin{tabular}{|c|c|c|c|c|c|c|}
\hline 1. & $\begin{array}{l}\text { Penyakit } \\
\text { kronis }\end{array}$ & $\begin{array}{l}\text { Ada / tidaknya pe- } \\
\text { nyakit kronis yang } \\
\text { diderita lansia yang } \\
\text { diderita minimal selama } \\
3 \text { bulan dan pernah } \\
\text { didiagnosa dokter. } \\
\text { Tidak meliputi keluhan } \\
\text { penyakit yang tidak } \\
\text { pernah dilakukan } \\
\text { pemeriksaan oleh } \\
\text { dokter. }\end{array}$ & Wawancara & Kuesioner & $\begin{array}{l}\text { Dikategorikan menjadi ada } \\
\text { dan tidak ada }\end{array}$ & Nominal \\
\hline 2. & $\begin{array}{l}\text { Jenis } \\
\text { penyakit } \\
\text { kronis }\end{array}$ & $\begin{array}{l}\text { Tipe dari penyakit } \\
\text { kronis }\end{array}$ & Wawancara & Kuesioner & $\begin{array}{l}\text { Dikategorikan menjadi } \\
\text { hipertensi, DM, gagal ginjal } \\
\text { kronis pasca stroke, } \\
\text { osteoartritis katarak, } \\
\text { penyakit saluran nafas, dan } \\
\text { penyakit kronis lainnya. }\end{array}$ & Nominal \\
\hline \multicolumn{7}{|c|}{ Kualitas hidup } \\
\hline 1. & $\begin{array}{l}\text { Kualitas } \\
\text { hidup }\end{array}$ & $\begin{array}{l}\text { Kualitas hidup adalah } \\
\text { skor yang diperoleh dari } \\
\text { hasil pengisian } \\
\text { kuesioner WHOQOL } \\
\text { BREF oleh responden } \\
\text { yang menggunakan } \\
\text { skala likert dengan } 5 \\
\text { titik (kisaran skor 1-5) } \\
\text { dan terdiri dari } 24 \\
\text { pertanyaan yang } \\
\text { meliputi } 4 \text { dimensi } \\
\text { kualitas hidup yaitu: } \\
\text { 1) kesehatan fisik, } \\
\text { 2) psikologis, } \\
\text { 3) sosial, dan } \\
\text { 4) lingkungan }\end{array}$ & Wawancara & $\begin{array}{l}\text { Kuesioner } \\
\text { WHOQOL } \\
\text { BREF }\end{array}$ & $\begin{array}{l}\text { Dikategorikan dalam kualitas } \\
\text { hidup rendah, kualitas hidup } \\
\text { sedang, kualitas hidup } \\
\text { tinggi. }\end{array}$ & Ordinal \\
\hline
\end{tabular}

Karakteristik Sosiodemografi dan Prevalensi Penyakit Kronis pada Responden

Responden penelitian ini adalah kelompok penduduk berusia 60 tahun ke atas yang tinggal di wilayah kerja UPT Puskesmas Petang II dan telah memberikan persetujuan ikut serta dalam penelitian. Responden dipilih dengan metode accidental sampling dan diperoleh jumlah sampel sebanyak 93 orang. Berdasarkan wawancara diperoleh karakteristik sosiodemografi responden meliputi jenis kelamin, umur, tingkat pendidikan, status pernikahan, dan pekerjaan.

Tabel 1. Karakteristik Sosiodemografi dan Prevalensi Penyakit Kronis pada Responden

\begin{tabular}{lcc}
\hline Karakteristik & Jumlah & $\%$ \\
& & \\
\hline Jenis kelamin & & \\
Laki-laki & 37 & 39,8 \\
Perempuan & 56 & 60,2 \\
\hline
\end{tabular}

\begin{tabular}{lcc} 
Usia (mean \pm SD) & \multicolumn{2}{c}{$(71,38 \pm 8,47)$} \\
$\quad$ 60-74 tahun & 71 & 76,3 \\
$\quad 75$ tahun & 22 & 23,7 \\
\hline Status Pendidikan & & \\
$\quad$ Tidak sekolah & 38 & 40,9 \\
$\quad$ Tidak tamat SD & 24 & 25,8 \\
$\quad$ Tamat SD & 29 & 31,2 \\
$\quad$ SMP & 2 & 2,2 \\
\hline Status Perkawinan & & \\
Menikah & 44 & 47,3 \\
$\quad$ Duda/janda & 49 & 52,7 \\
\hline Pekerjaan & & \\
Bekerja & 44 & 47,3 \\
$\quad$ Tidak bekerja & 49 & 52,7 \\
\hline Penyakit kronis & & \\
Ada & 71 & 76,3 \\
Tidak & 22 & 23,7 \\
\hline
\end{tabular}

Pada penelitian ini didapatkan sebagian besar responden berjenis kelamin perempuan (60,2\%). Rata-rata usia responden adalah 71,3 tahun, dengan usia termuda 60 tahun dan usia tertua 97 
tahun. Dari data kelompok umur didapatkan bahwa responden sebagian besar pada kelompok umur 60-74 tahun (eldery age). Berdasarkan tingkat pendidikan, proporsi responden yang tidak tamat SD ditemukan paling tinggi yaitu sebesar $40,9 \%$, Ditinjau dari status perkawinan, mayoritas responden berstatus duda/janda. Disamping itu, mayoritas responden juga sudah tidak bekerja $(52,7 \%)$,

Dari hasil wawancara mengenai penyakit kronis, sebanyak 71 responden (35,6\%) mengaku memiliki penyakit kronis yang telah didiagnosis oleh dokter. Proporsi laki-laki yang memiliki penyakit kronis $(75,6 \%)$ sedikit lebih rendah dibandingkan dengan proporsi perempuan yang memiliki penyakit kronis (76,8\%).

Dari 71 responden yang menderita penyakit kronis, osteoartritis adalah jenis penyakit kronis yang paling banyak diderita oleh responden, yakni sebanyak 42 kasus $(45,2 \%)$. Penyakit kronis lain yang diderita responden antara lain, hipertensi, katarak, DM dan penyakit saluran nafas.

Tabel 2. Frekuensi jenis penyakit kronis yang diderita responden

\begin{tabular}{lcc}
\hline \multirow{2}{*}{ Jenis Penyakit Kronis } & \multicolumn{2}{c}{ Total } \\
\cline { 2 - 3 } & N & $\%$ \\
\hline Osteoarthritis & 42 & 45,2 \\
Hipertensi & 24 & 25,8 \\
Katarak & 5 & 5,4 \\
DM & 4 & 4,3 \\
Penyakit saluran napas & 2 & 9,5 \\
Penyakit lainnya & 17 & 23,8 \\
\hline
\end{tabular}

$\mathrm{n}=$ jumlah responden, 1 orang lansia dapat menderita lebih dari 1 jenis penyakit kronis.

\section{Distribusi Status Depresi dan Kualitas Hidup Lansia}

Hasil penentuan status depresi pada responden menggunakan kuesioner GDS-15 diperoleh jumlah lansia yang mengalami depresi $(21,5 \%)$ lebih rendah dibandingkan lansia yang tidak mengalami depresi (78,5\%). Pengukuran status depresi dengan menggunakan GDS-15 tidak dapat menentukan keparahan dari depresi yang dialami responden. Dari hasil tersebut juga diperoleh bahwa lansia perempuan lebih banyak mengalami depresi dibandingkan dengan lansia laki-laki namun dengan perbedaan yang tidak terlalu besar.
Penilaian kualitas hidup pada penelitian ini menggunakan kuesioner WHOQOL BREF yang menilai kualitas hidup dari total skor hasil penjumlahan masing-masing domain kualitas hidup yaitu domain fisik, psikologis, sosial, dan lingkungan, kemudian dibagi 4. Total skor kualitas hidup selanjutnya dikelompokkan menjadi kualitas hidup baik dan kualitas hidup buruk. Ratarata kualitas hidup subjek adalah 49,2 dengan nilai median sebesar 48. Dalam hal ini nilai median yang digunakan untuk menentukan kelompok kualitas hidup lansia sehingga diperoleh jumlah subjek yang memiliki kualitas hidup baik adalah sebanyak 46 orang $(49,5 \%)$ dan yang memiliki kualitas hidup buruk adalah 47 orang $(50,5 \%)$

Tabel 3. Distribusi status depresi dan kualitas hidup responden

\begin{tabular}{lcccc}
\hline & \multicolumn{4}{c}{ Jenis Kelamin } \\
\cline { 2 - 5 } Variabel & Pria & $\%$ & Wanita & $\%$ \\
\hline Status & & & & \\
Depresi & & & & \\
$\quad$ Depresi & 7 & 18,9 & 13 & 23,2 \\
$\quad$ Non & 30 & 81,1 & 43 & 76,8 \\
$\quad$ depresi & & & & \\
\hline
\end{tabular}

Pada tabel 4 telah dijabarkan tingkat kualitas hidup berdasarkan domain penyusun kualitas hidup. Tingkat kualitas hidup buruk ditemukan lebih tinggi pada domain fisik dan lingkungan.

Tabel 4. Distribusi tingkat kualitas hidup responden berdasarkan skor per domain kualitas hidup

\begin{tabular}{lcccc}
\hline \multirow{2}{*}{ Variabel } & \multicolumn{4}{c}{ Kualitas Hidup } \\
\cline { 2 - 5 } & \multicolumn{3}{c}{ Baik } & \multicolumn{2}{c}{ Buruk } \\
\cline { 2 - 5 } & $\mathbf{n}$ & $\%$ & $\mathbf{n}$ & $\%$ \\
\hline $\begin{array}{l}\text { Jenis Kelamin } \\
\quad \text { Laki }\end{array}$ & 18 & 48,6 & 19 & 51,4 \\
$\quad$ Perempuan & 28 & 50 & 28 & 50 \\
Domain & & & & \\
$\quad$ Fisik & 44 & 47,3 & 49 & 52,7 \\
\hline$\quad$ Psikologis & 61 & 65,6 & 32 & 34,4 \\
\hline$\quad$ Sosial & 61 & 65,6 & 32 & 34,4 \\
\hline$\quad$ Lingkungan & 45 & 48,4 & 48 & 51,6 \\
\hline
\end{tabular}

Hubungan Status Depresi dengan Kualitas Hidup Lansia

Penilaian terhadap variabel seperti status depresi dilakukan untuk mengetahui hubungannya terhadap kualitas hidup lansia. Maka dari itu 
dilakukan analisis hubungan dan analisi risiko untuk lebih memahami hubungan antara variabel tersebut.

Dari analisis hubungan antara status depresi dengan kualitas hidup lansia diperoleh bahwa responden yang tidak mengalami depresi $(61,6 \%)$ memiliki kualitas hidup baik lebih tinggi dibandingankan dengan responden yang mengalami depresi. Uji analisis chi-square terhadap variabel tersebut menunjukkan hubungan yang signifikan antara status depresi dengan kualitas hidup lansia $(p<0,05)$. Nilai yang diperoleh dari analisis risiko menyatakan bahwa lansia dengan kualitas hidup yang buruk memiliki kecenderungan 30,56 kali lebih besar untuk mengalami depresi.

Tabel 5. Distribusi Kualitas Hidup Berdasarkan Status Depresi

\begin{tabular}{lcccc}
\hline \multirow{2}{*}{ Variabel } & \multicolumn{3}{c}{ Kualitas Hidup } \\
\cline { 2 - 5 } & \multicolumn{2}{c}{ Buruk } & \multicolumn{2}{c}{ Baik } \\
\cline { 2 - 5 } & $\mathbf{n}$ & $\%$ & $\mathbf{n}$ & $\%$ \\
\hline Depresi & 19 & 95,0 & 1 & 5,0 \\
Non & 28 & 38,4 & 45 & 61,6 \\
\hline & & &
\end{tabular}

Dari hasil uji analisis tersebut tersebut, diperlukan kajian lebih lanjut untuk mengetahui variabel perancu yang memiliki hubungan bermakna dengan kualitas hidup lansia. Selanjutnya, variabel perancu yang memiliki hubungan yang bermakna tersebut akan digunakan untuk melakukan analisis terstratifikasi untuk mengetahui modifikasi variabel perancu terhadap hubungan antara status depresi dengan kualitas hidup.

Pada tabel 6 telah dijabarkan mengenai hubungan dari setiap variabel perancu. Hasil analisis tersebut menunujukkan bahwa beberapa variabel perancu memiliki hubungan yang bermakna terhadap kualitas hidup lansia. Adapun variabel yang memiliki hubungan yang bermakna yakni usia, status perkawinan dan pekerjaan. Dalam hal ini, jenis kelamin tidak menunjukkan hubungan yang bermakna dengan kualitas hidup $(p=0,898)$ sehingga tidak akan digunakan untuk analisis lebih lanjut.

Tabel 6. Distribusi Kualitas Hidup Berdasarkan Karakteristik Sosiedemografik dan Prevalensi Penyakit Kronis.

\begin{tabular}{|c|c|c|c|c|c|}
\hline \multirow{3}{*}{ Karakteristik } & \multicolumn{4}{|c|}{ Kualitas Hidup } & \multirow{3}{*}{ P-value } \\
\hline & \multicolumn{2}{|c|}{ Baik } & \multicolumn{2}{|c|}{ Buruk } & \\
\hline & $\mathbf{N}$ & $\%$ & $\mathbf{N}$ & $\%$ & \\
\hline \multicolumn{6}{|l|}{ Jenis } \\
\hline Kelamin & 18 & 48,6 & 19 & 51,4 & 0,898 \\
\hline Laki-laki & 28 & 50,0 & 28 & 50,0 & \\
\hline \multicolumn{6}{|l|}{ Perempuan } \\
\hline \multicolumn{6}{|l|}{ Kelompok } \\
\hline usia & 41 & 57,7 & 30 & 42,3 & 0,004 \\
\hline $60-74$ & 5 & 22,7 & 17 & 77,3 & \\
\hline \multicolumn{6}{|l|}{ tahun } \\
\hline \multicolumn{6}{|l|}{$>75$ tahun } \\
\hline \multicolumn{6}{|l|}{ Status } \\
\hline Perkawinan & 30 & 68,2 & 14 & 31,8 & 0,001 \\
\hline Menikah & 46 & 32,7 & 47 & 67,3 & \\
\hline \multicolumn{6}{|l|}{ Janda/Duda } \\
\hline \multicolumn{6}{|l|}{ Pekerjaan } \\
\hline Bekerja & 36 & 81,8 & 8 & 18,2 & 0,000 \\
\hline Tidak & 46 & 20,4 & 47 & 79,6 & \\
\hline \multicolumn{6}{|l|}{ Bekerja } \\
\hline \multicolumn{6}{|l|}{ Penyakit } \\
\hline Kronis & 27 & 38,0 & 44 & 62,0 & 0,000 \\
\hline Ada & 46 & 86,4 & 47 & 13,6 & \\
\hline Tidak ada & & & & & \\
\hline
\end{tabular}

Tabel 7. Distribusi Kualitas Hidup Berdasarkan Status Depresi dengan Stratifikasi Kelompok Usia

\begin{tabular}{llcccc}
\hline \multirow{2}{*}{ Usia } & \multirow{2}{*}{ Karakter } & \multicolumn{2}{c}{ Kualitas Hidup } & & \\
\cline { 3 - 4 } & & Buruk & Baik & OR & 95\%Cl \\
\cline { 3 - 4 } & & $\mathbf{n}(\%)$ & $\mathbf{n ~ ( \% )}$ & & \\
\hline \hline $60-74$ & Depresi & 10 & 1 & & \\
tahu & & $(90,9)$ & $(9,1)$ & 20 & $2,39-$ \\
$\mathrm{n}$ & & & & & 167,3 \\
& Non & 20 & 40 & & 8 \\
& Depresi & $(33,3)$ & $(66,7)$ & & \\
\hline$>75$ & Depresi & 9 & 0 & & \\
tahu & & $(100 \%)$ & $(0)$ & 11, & \\
$\mathrm{n}$ & & & & 25 & \\
& Non & 8 & 5 & & \\
& Depresi & $(61,5)$ & $(38,5)$ & & \\
\hline \hline
\end{tabular}

Analisis terstratifikasi berdasarkan kelompok usia menunjukkan bahwa lansia pada kelompok umur 60-74 tahun dengan kualitas hidup yang buruk mempunyai kecenderungan untuk menderita depresi 20 kali lebih tinggi. Sedangkan pada kelompok umur $>75$ tahun dengan kualitas hidup yang buruk memiliki kecendrungan mengalami depresi 11,25 kali lebih tinggi (tabel 7).

Tabel 8. Distribusi Kualitas Hidup Berdasarkan Status Depresi dengan Stratifikasi Status Pernikahan

\begin{tabular}{ccccc}
\hline \multirow{2}{*}{ Status } & Karakter & \multicolumn{2}{c}{ Kualitas Hidup } & \\
& Buruk Baik & OR & 95\%Cl
\end{tabular}




\begin{tabular}{llccll}
\hline & & $\mathbf{n}(\%)$ & $\mathbf{n ~ ( \% )}$ & & \\
\cline { 3 - 5 } \cline { 3 - 5 } Menikah & Depresi & 5 & 1 & & \\
& & $(83,3)$ & $(16,7)$ & 16,11 & $1,65-$ \\
& & & & & 156,5 \\
& Non & 9 & 29 & & \\
& Depresi & $(23,7)$ & $(76,3)$ & & \\
\hline Duda/ & Depresi & 14 & 0 & & \\
Janda & & $(100)$ & $(0)$ & 0,042 & \\
& & & & & \\
& Non & 19 & 16 & & \\
& Depresi & $(54,3)$ & $(45,7)$ & & \\
\hline
\end{tabular}

Statifikasi berdasarkan status pernikahan menunjukkan bahwa yang menikah dan masih memiliki pasangan hidup dengan kualitas hidup yang buruk memiliki kecendrungan untuk menderita depresi 16,11 kali lebih tinggi. Sedangkan pada kelompok duda/janda dengan kualitas hidup yang buruk memiliki kecendrungan mengalami depresi sebesar 0,042 kali (tabel 8).

Tabel 9. Distribusi Kualitas Hidup Berdasarkan Status Depresi dengan Stratifikasi Penyakit Kronis

\begin{tabular}{|c|c|c|c|c|c|}
\hline \multirow{3}{*}{$\begin{array}{c}\text { Penyakit } \\
\text { Kronis }\end{array}$} & \multirow{3}{*}{$\begin{array}{c}\text { Karakte } \\
\text { ristik }\end{array}$} & \multicolumn{2}{|c|}{ Kualitas Hidup } & \multirow{3}{*}{ OR } & \multirow{3}{*}{$\begin{array}{c}95 \% C \\
1\end{array}$} \\
\hline & & Buruk & Baik & & \\
\hline & & n (\%) & n (\%) & & \\
\hline \multirow[t]{4}{*}{ Ada } & Depresi & 19 & 1 & & \\
\hline & & $(95,0)$ & $(5,0)$ & 19,76 & $\begin{array}{l}2,46- \\
158,8\end{array}$ \\
\hline & Non & 25 & 26 & & 8 \\
\hline & Depresi & $(49,0)$ & $(51,0)$ & & \\
\hline \multirow[t]{4}{*}{ Tidak } & Depresi & 0 & 0 & & \\
\hline & & (0) & (0) & 1,6 & \\
\hline & Non & 45 & 28 & & \\
\hline & Depresi & $(61,60)$ & $(38,4)$ & & \\
\hline
\end{tabular}

Uji hubungan dengan stratifikasi berdasarkan penyakit kornis menunjukkan bahwa lansia yang mengidap penyakit kronis dengan kualitas hidup yang buruk memiliki kecendrungan untuk menderita depresi 19,76 kali lebih tinggi. Sedangkan pada lansia yang tidak memiliki penyakit kronis dengan kualitas hidup yang buruk memiliki kecendrungan mengalami depresi 1,6 kali lebih tinggi (tabel 9).

\section{Simpulan}

Berdasarkan hasil penelitian tentang kualitas hidup lansia di wilayah kerja Puskesmas Petang II dapat dibuat kesimpulan sebagai berikut:

1. Karakteristik demografi dan sosial ekonomi responden antara lain, jumlah responden perempuan lebih banyak dibandingkan responden laki-laki, mayoritas responden berusia antara 60 74 tahun, tingkat pendidikan responden terbanyak adalah tidak tamat sekolah, dan lebih dari setengah responden berstatus duda/janda, serta sudah tidak bekerja. Dilihat dari penyakit kronis pada lansia, 76,3\% responden mengaku memiliki penyakit kronis, dengan kejadian penyakit kronis tertinggi ditemukan pada lansia perempuan dan lansia berusia $\geq 70$ tahun, dan jenis penyakit kronis yang paling banyak diderita adalah osteoartritis.

2. Gambaran kualitas hidup lansia di wilayah kerja Puskesmas Petang II secara umum telihat lebih banyak jumlah lansia memiliki kualitas hidup buruk (50,5\%) namun dengan selisih yang kecil dibandingkan kualitas hidup baik. Bila dilihat per domain, masih ditemukan tingkat kualititas hidup rendah pada domain fisik dan lingkungan.

3. Status Depresi memiliki hubungan yang bermakna dengan kualitas hidup namun tidak demikian halnya dengan status kognitif. Hasil analisis risiko menunjukkan lansia yang tanpa depresi memiliki kecendrungan sebesar 30,56 kali untuk memiliki kualitas hidup yang baik.

\section{Saran}

Berdasarkan hasil penelitian dan pembahasan, maka penulis memberikan rekomendasi pada berbagai pihak antara lain sebagai berikut:

1. Pembentukan kelompok khusus lansia dengan penyakit kronis khususnya penyakit osteoartritis, hipertensi dan katarak sehingga dapat dilakuan upaya peningkatan kualitas hidup terkait domain fisik, psikologis, sosial, dan lingkungan secara lebih terfokus.

2. Diharapkan dilakukan penelitian lebih lanjut mengenai faktor-faktor yang dapat mempengaruhi kualitas hidup lansia di Desa Petang.

\section{DAFTAR PUSTAKA}

1. United Nation. (2013), "World Population Ageing 2013". New York: United Nation. Pp: 195.

2. BPS Provinsi Bali. (2013), "Statistik Daerah Provinsi Bali Tahun 2012. Denpasar: Badan Pusat Statistik Provinsi Bali.

3. Mudey, A., et al. (2011), "Assessment of Quality of Life among Rural and Urban Elderly 
Population of Wardha District, Maharashtra, India". Ethno Med, vol. 5, no. 2, pp. 89-93.

4. Qadri, S., et al. (2013), An Epidemiological Study on Quality of Life Among Rural Elderly Population of Northern India. International Journal of Medical Science and Public Health. 2013; 2(3): 514-522.

5. Yuliati, dkk. (2014), “Perbedaan Kualitas Hidup Lansia yang Tinggal di Komunitas dengan di Pelayanan Sosial Lanjut Usia". e-Jurnal Pustaka Kesehatan, vol. 2, no. 1.

6. Bodur, S. et al. (2009), "Using WHOQOL-BREF to Evaluate Quality of Life among Turkish Elders in Different Residential Environments". J Nutr Health Aging ., vol. 13, no. 7, pp. 652-6.

7. Canbaz, S., et al. (2003), "The Prevalence of Chronic Disease and Quality of Life in Elderly People in Samsun". Turk J Med Sci, vol. 33, pp 335-340.

8. Yenny dan Herwana, E. (2006), “Prevalensi Penyakit Kronis dan Kualitas Hidup Pada Lanjut Usia di Jakarta Selatan". Universa Medicina, vol. 25, no. 4, pp. 164-171.

9. Depkes RI. (2003), "Pedoman Pengelolaan Kegiatan Kesehatan di Kelompok Usia Lanjut". Depkes: Jakarta. 2003.

10. Ekawati. (2010). "Hubungan Fungsi Keluarga dengan Kualitas Hidup Lansia". Available at: http://perpustakaan.uns.ac.id Akses: 20 Maret 2015.

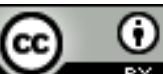

This work is licensed under A Creative Commons Attribution 